\title{
Predation by Norway rats in the intertidal zone of central Chile
}

\author{
Sergio A. Navarrete*, Juan C. Castilla \\ Estación Costera de Investigaciones Marinas, Las Cruces, Facultad de Ciencias Biológicas, P. Universidad \\ Católica de Chile, Casilla 114-D, Santiago, Chile
}

\begin{abstract}
The rocky intertidal zone of central Chile comprises a diverse array of invertebrate and vertebrate (i.e. birds, fish, humans) predators. In this system, like in most temperate rocky shores, predation by small 'terrestrial' mammals such as mice and rats has been largely overlooked. This study documents predation on intertidal organisms by Norway rats Rattus norvegicus in a marine preserve in Las Cruces, central Chile. Five species of small mammals, 3 endemic and 2 introduced, were found in the littoral zone of the marine preserve. $R$. norvegicus was the most abundant of these species throughout the year-long mark-recapture study. Ten burrows of $R$. norvegicus containing remains of intertidal organisms were located in the littoral zone, 8 inside the marine preserve and 2 ca $200 \mathrm{~m}$ outside. Remains found in the burrows and stomach content analyses showed that rats prey on 40 different intertidal species, including both mobile and sessile organisms from the mid to the very low intertidal zone. The most numerous prey species in the burrows were keyhole limpets (490 individuals), mostly Fissurella crassa, followed by porcelanid crabs (187 individuals) and cancrid crabs of the genus Acanthocyclus (101 individuals). Prey composition in the burrows varied greatly. Some burrows were dominated by keyhole limpets and others by crabs, suggesting some degree of specialization by individual rats. Comparison between keyhole limpets found in burrows and on intertidal rocks inside the marine preserve showed that rats remove the smaller, less abundant sizes of keyhole limpets from the population, probably due to mechanical restrictions to dislodging larger individuals. The number of small keyhole limpets $(<55 \mathrm{~mm}$ long) that Norway rats can potentially remove from the marine preserve in a year (over 8730 ) as compared to numbers of small limpets in the preserve, suggest that $R$. norvegicus may have important effects on the population structure and abundance of these species. Since humans deplete keyhole limpet populations outside the marine preserve, rats may compensate for part of the effects of humans harvesting inside the preserve. Preliminary data suggest that rats are less abundant in places distant from human populations and thus the proximity to human populations can be an important factor in deciding the location of marine preserves.
\end{abstract}

\section{INTRODUCTION}

Predation, together with a variety of other factors, is an important process regulating populations and communities (e.g. Paine 1966, Connell 1975, Menge \& Sutherland 1987, Menge \& Farrell 1989, Schoener 1989). This is particularly true in aquatic and rocky intertidal systems, where predators can have dramatic effects on the composition and relative abundance of species (Sih et al. 1985, Kerfoot \& Sih 1987). Rocky

\footnotetext{
- Present address: Department of Zoology, Oregon State University, Corvallis, Oregon 97331-2914, USA
}

intertidal communities often include a diverse array of predators, including both vertebrate and invertebrate species (Lewis 1964, Menge 1983, Feare \& Summers 1986, Hughes 1986, Castilla \& Paine 1987). Although some of these communities seem to be dominated by the action of only one or a few predators (Paine 1966, 1980), knowledge about the effects of all or most predator species is necessary in order to fully evaluate the impact of predation on community pattern and its variation (e.g. Gaines 1983, 1985, Menge et al. 1985, Abrams 1987).

Predators are particularly dominant in the rocky intertidal zone of central Chile (Castilla 1981, Castilla 
\& Paine 1987), Some studies have experimentally shown the important, community-wide effects of some of these species (Castilla \& Durán 1985, Paine et al. 1985, Durán \& Castilla 1989), while others have suggested the potential effects of other predators, such as crabs and fish, on their prey populations (e.g. Paine \& Palmer 1978, Castilla 1981, Cancino \& Castilla 1988, Navarrete \& Castilla 1988, 1990a). Humans are also part of the set of predators that exert their effects on intertidal communities. The installation of marine preserves from which humans were excluded demonstrated the dramatic effect of human harvesting on the intertidal seascape (Castilla \& Durán 1985, Castilla 1988, Durán \& Castilla 1989, Marquet et al. 1990). Effects of humans have also been experimentally demonstrated in southern Chile (Moreno et al. 1984, 1986). In the intertidal zone of central Chile, where predation is a dominant structuring factor, little or no attention has been given to a set of 'terrestrial' and unusual predators, namely mice and rats. In fact, predation by such organisms on intertidal communities has been overlooked or considered a priori of no importance by most marine ecologists around the world (but see Fig. 2 of Menge \& Sutherland 1987).

In general, quantification and experimental assessment of the effects of highly mobile predators (e.g. birds, fish, crabs, rats) on intertidal organisms represent an important challenge, mostly because of the difficulty of excluding them from a large enough area while allowing free access by other species (see Edwards et al. 1982, Menge 1982, Castilla \& Paine 1987, Robles 1987 for discussions). However, using ingenious designs a few studies have demonstrated the significant effects of mobile predators such as birds (Marsh 1986), fish (Menge et al. 1985, 1986), crabs (Peterson 1979), and lobsters (Robles 1987). Likewise. small mammals (e.g. rats, mice), which can have relatively large foraging ambits and can cover large areas of coast quicker than their invertebrate counterparts, could also have important effects on prey communities.

Several instances of predation by small mammals on littoral invertebrates of rivers and lakes have been documented (e.g. Van Cleave 1940, Parisi \& Gandolfi 1974, Nieder et al. 1977. Hanson et al. 1989. Stewart et al. 1989). However, similar information for marine littoral zones is rather anecdotal (e.g. Frank 1965). Only recently 2 notes reported predation by mice and rats on marine intertidal organisms in southern Chile (Martínez et al. 1986, Zamorano 1986). The presence of burrows with shell remains inside a marine preserve in central Chile and the sporadic sightings of rats and mice in the littoral zone by local people motivated us to take a closer look at predation by these highly mobile organisms. Here we describe and quantify predation by the most abundant of these species, the Norway rat
Rattus norvegicus, in an effort to gain insight into the effects this species might have on intertidal prey populations and communities.

\section{MATERIAL AND METHODS}

This study was conducted in Las Cruces, central Chile $\left(33^{\circ} 30^{\prime} \mathrm{S}, 71^{\circ} 38^{\prime} \mathrm{W}\right)$, where the marine preserve Estación Costera de Investigaciones Marinas (ECIM) of the Universidad Católica de Chile is located. The exclusion of humans from this marine preserve in 1982 resulted in important changes in the populations of invertebrates, which in turn had cascading effects in the entire community (see e.g. Castilla \& Durán 1985, Oliva \& Castilla 1986, Durán et al. 1987, Castilla 1988, Bustamante \& Castilla 1990, Marquet et al. 1990). Detailed descriptions of the intertidal zone of central Chile can be found in the references above and in Durán \& Castilla (1989), Santelices (1989, 1990), and Navarrete \& Castilla $(1990 \mathrm{a}, \mathrm{b})$.

To determine which species of small mammals inhubit the littoral zone inside the preserve and to estimate their abundance, a mark-recapture study was conducted from May 1988 through March 1989. Two transects about $110 \mathrm{~m}$ long and $10 \mathrm{~m}$ apart were established parallel to the coastline in the southern part of the marine preserve. The transects covered a ca $1100 \mathrm{~m}^{2}$ area of littoral zone of the total ca $89400 \mathrm{~m}^{2}$ in the preserve (measured from aerial pictures). This littoral zone is a strip of land about $90 \mathrm{~m}$ wide (range 60 to $130 \mathrm{~m}$ ), delimited landward by a $30 \mathrm{~m}$ high vertical cliff and seaward by the high water level. The lower (seaward) transect ran mainly across the rocks at the maximum high water level; the other (landward) transect followed the shoreward border of the terrestrial vegetation. Eleven trapping stations were established every ca $10 \mathrm{~m}$ along each of the transects. In each station 2 traps were used: a regular size Sherman trap $(75 \times 85 \times 240 \mathrm{~mm})$ to capture small animals, and a Tomahawk $(170 \times 190 \times 600 \mathrm{~mm})$ to capture larger animals. A total of 22 pairs of traps were baited with rolled oats at sundown for 6 consecutive days and checked early the next morning. Trapping was conducted monthly, except for June and December 1988. Animals captured in the traps were weighed, measured (body length and total length including tail), marked by toe-clipping and then released at the place of capture. Large animals were anesthetized with ether to facilitate marking and then allowed to completely recover before being freed. In August 1988 and February 19892 parallel transects with the same number of traps were also set in Punta Salinas, a locality outside the marine preserve, about $1500 \mathrm{~m}$ north of the village of Las Cruces. 
Rodent abundances were estimated using Chapman's modification of the Lincoln-Petersen index $\left(N^{\prime}\right)$ for mark-recapture data (Seber 1982, 1986). This index has been shown to be the least biased estimator for small populations when there is no previous knowledge about the behavior of the species (Menkens \& Anderson 1988). Confidence intervals (Cl) for the estimated population size were obtained using Chapman's equation of variance $\left(V^{*}\right)$ with the assumption of an approximately normal distribution $\left(\mathrm{Cl}=1.96 \sqrt{V^{\circ}}\right.$; Seber 1982). Because the Lincoln-Petersen estimator uses data from only 2 trapping periods, data from the first 3 days and second 3 days of trapping were pooled, as suggested by Menkens \& Anderson (1988). Pooling of data in symmetrical periods reduces the number of parameters and improves the performance of the index (Menkens \& Anderson 1988). The conversion of the estimated number of animals $\left(N^{*}\right)$ to density requires knowledge of the effective area sampled by the traps (Seber 1982). Estimation of this area using recapture information was complicated in this study by 2 factors: (1) since trapping was aimed at the animals inhabiting a strip of land next to the intertidal zone (littoral zone) we did not use a grid of equally spaced traps in all directions, hampering the estimation of home ranges and area sampled (see Seber 1982, 1986, Wilson \& Anderson 1985, for discussions); (2) the low number of traps and low number of animals captured precluded the use of the nested subgrids method (e.g. Otis et al. 1978). With this restrictions, the effective area sampled by traps was estimated by adding $1 / 2$ the average home range diameter of the species, obtained from the literature, to the outermost line of traps (Dice 1938, Tanaka 1980, Seber 1982). Assuming circular home ranges of about 0.35 ha for Rattus norvegicus (Calhoun 1962) and 0.15 ha for Akodon olivaceus (Redford \& Eisenberg 1992), the effective areas sampled for these species are 13560 and $8316 \mathrm{~m}^{2}$ respectively.

To study the stomach content of rodents, 2 transects of snap-traps were established parallel to the coastline about $50 \mathrm{~m}$ outside the marine preserve in Las Cruces and in Punta de Tralca, about $12 \mathrm{~km}$ north of Las Cruces. We did not trap animals for stomach content analyses inside the marine preserve to avoid killing animals there. However, because of the mobility of these rodents (see below), some of the animals captured in Las Cruces outside the preserve might have come from inside. The position of the transects with respect to the coastline was similar to the livetrap transects. A total of 50 regularly spaced traps along the transects operated for 4 to $10 \mathrm{~d}$ in May and December 1988, January and February 1989, and February 1992. Traps baited with rolled oats were set at sundown and checked the next morning. Animals captured in the traps were weighed, measured, labeled and frozen for later analysis. The stomachs of the animals were removed and analyzed under a dissecting scope. Prey items were identified to the lowest possible taxonomic level. Quantification of prey items in the stomachs was not possible because of the irregular mix of finely grained hard remains (e.g. shell pieces) with fleshy contents (e.g. green plants, muscle tissue) and the bait.

In March 1987, 8 burrows with remains of intertidal organisms and rodent feces were located inside the marine preserve. Two more burrows were located about $200 \mathrm{~m}$ beyond the southern boundary of the preserve. Burrows were non-destructively monitored every month from May 1988 through March 1989. All remains of prey inside burrows were collected and identified to the lowest possible taxonomic level, measured when possible (e.g. total shell length of limpets, carapace width or height of claw of crabs), and marked with permanent blue ink. All fragments of shell or carapaces (if broken) were marked and only main fragments (e.g. claws, plates of chitons) were considered in a conservative manner (e.g. 1 to 8 chiton plates $=1$ individual). Remains were then returned to the respective burrows to avoid disturbing the animals using them. Prey biomass was estimated by using appropriate regression equations relating characteristic dimensions with fresh weight. When a regression was not available for a particular species, the relation for a closely related, similarly sized species was used.

To identify the species using the burrows during the course of the study without disturbing the animals, smoked cardboard plates were placed around the entrances of all burrows for 3 to $5 \mathrm{~d}$ in several different months. Animals leave their tracks imprinted in these plates when entering and leaving the burrow (see Justice 1961). Reference patterns of tracks for all the species captured in the littoral zone were obtained in the laboratory by allowing live animals to freely walk on smoked plates. Comparisons of these patterns with the tracks obtained in the field helped to determine the species using the burrows. Further confirmation of rodent identities were obtained by the end of the study (February and March 1989), by placing livetraps in burrow entrances for several days and identifying the animals captured.

Because of the differences in the structure of communities inside and outside the marine preserve (Durán \& Castilla 1989, Marquet et al. 1990) the prey composition of burrows inside the preserve was compared with that of the burrows outside. To conduct such comparison and take simultaneously into account both the variations and co-variations of the number of individuals of all 36 prey species, the Bray-Curtis (Polar) multivariate ordination technique was used. The minimum variance procedure was used to select the endpoints for construction of multivariate orthogo- 
nal axes (Beals 1984). To improve the representation of burrows in the multivariate axes, results obtained by Bray-Curtis were subjected to non-metric multidimensional scaling (NMS; Kruscal 1964). This technique reduces the dissimilarity between the ranking of original distances between burrows and the distances in the new multivariate axes (Kruscal 1964, Beals 1984, McCune 1991). These analyses were conducted using the program PC-Ord (McCune 1991).

To determine if Norway rats were able to eat live invertebrates and if they left some identifiable marks in the remains, individual rats were offered porcelanid crabs Petrolisthes violaceous and keyhole limpets Fissurella crassa in the laboratory. Four rats, previously fed on oats, were placed separately in large plastic containers (ca $1.5 \mathrm{~m}$ diameter) for 1 night and offered crabs, keyhole limpets attached to rocks, ham, and oats ad libitum. The bottom of the container was kept wet with sea water to provide a humid atmosphere for the invertebrates. The relative abundances of different sizes of the most important prey species found in the burrows were compared with the relative abundances of those sizes in the field (marine proscrve). The size distribution in the field was determined in $1 \mathrm{~m}$ wide transects parallel to the coastline in 4 exposed and 4 protected rocky benches at the low, mid and high intertidal zone. Length of transects varied between 5 and $15 \mathrm{~m}$. Along the transects, all individuals of the species of interest were counted and measured.

\section{RESULTS}

\section{Population estimates}

Four species of small mammals were captured in the livetraps inside the marine preserve, the cricetid rodents Akodon olivaceus ('ratón oliváceo') and Oryzomis longicaudatus ('colilargo'), the marsupial (Marsupicarnivora) Marmosa elegans ('yaca'), and the murid Rattus norvegicus. A fifth species, the house mouse Mus musculus, was captured only in snap traps

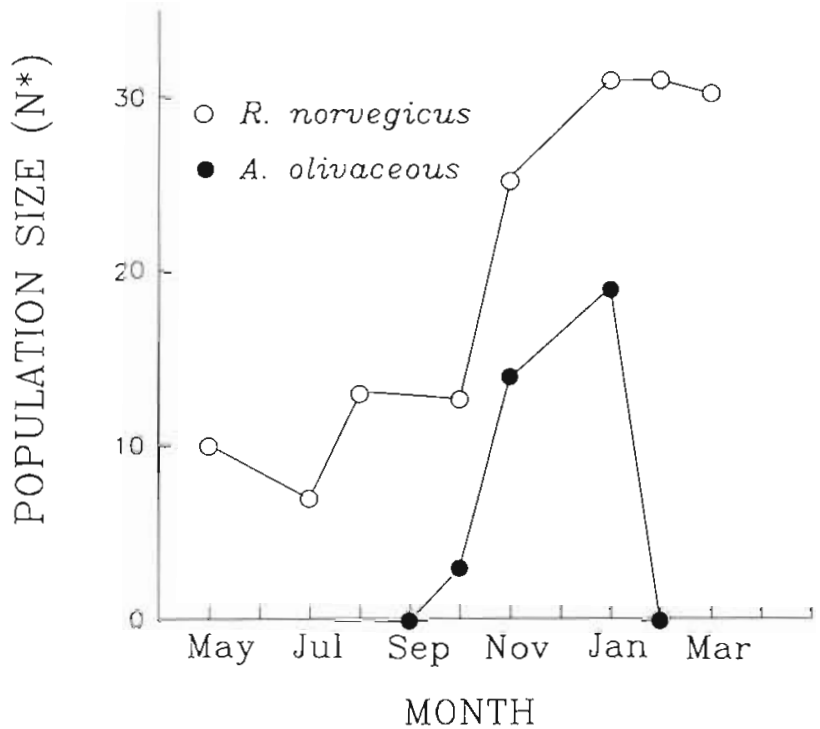

Fig. 1. Population size $\left(N^{*}\right)$ of rodents inside the marine preserve of Las Cruces, central Chile, during the course of the study (May 1988 through March 1989). Population sizes were estimated using the Lincoln-Petersen index for mark-recapture data. Sampled areas were 13560 and $8316 \mathrm{~m}^{2}$ for Rattus

norvegicus and Akodon olivaceus, respectively (see text)

outside the marine preserve (Table 1). The largest (range 91.9 to $364.5 \mathrm{~g}$ body weight) and most abundant of these species throughout the study was $R$. norvegicus (Table 1), which was captured only in Tomahawk and snap traps. The second most abundant species, $A$. olivaceus was captured in summer months (Fig. 1) mainly in Sherman, but also in Tomahawk traps. Marmosa elegans and $O$. longicaudatus were captured only in Sherman traps. The low numbers of the last 2 species precluded us from estimating their abundance (population size). All species were captured at least once in the lower (shoreward) transect. The only species exhibiting a clear, detectable bias for the traps was $M$. elegans. Individuals of this species became trap prone and were repeatedly captured over consecutive days.

Estimates of population size for Rattus norvegicus

Table 1. Average body weight, body length and total length ( $\pm \mathrm{SE}$ ) of the species of small mammals found in the littoral zone of Las Cruses, Chile, between February 1988 and March 1989

\begin{tabular}{|lrrrr|}
\hline Species & $\mathrm{n}$ & $\begin{array}{c}\text { Weight } \\
(\mathrm{g})\end{array}$ & $\begin{array}{c}\text { Body length } \\
(\mathrm{cm})\end{array}$ & $\begin{array}{c}\text { Total length } \\
(\mathrm{cm})\end{array}$ \\
\hline Rattus norvegicus & & $193.8 \pm 10.1$ & $18.7 \pm 0.3$ & $35.7 \pm 0.6$ \\
Akodon olivaceous & 35 & $48.5 \pm 4.2$ & $11.1 \pm 0.6$ & $19.9 \pm 1.5$ \\
Oryzomis longicaudatus & 10 & $21.5 \pm 4.1$ & $7.5 \pm 0.3$ & $19.8 \pm 0.8$ \\
Mus musculus & 4 & $46.3 \pm 17.9$ & $16.7 \pm 7.1$ & $19.4 \pm 4.2$ \\
Marmosa elegans & 5 & $24.0 \pm 8.4$ & & $18.5 \pm 1.3$ \\
a Captured only in snap traps & 3 & & & \\
\end{tabular}


and Akodon olivaceus are presented in Fig. 1. The estimated areas sampled for Norway rats $\left(13560 \mathrm{~m}^{2}\right)$ and for $A$. olivaceus $\left(8316 \mathrm{~m}^{2}\right)$ represent ca 15.2 and $9.3 \%$

Table 2. Relative abundance ( $\%$ of total no. of individuals, $n=$ 997) of prey items found in burrows of Rattus norvegicus in Las Cruces (all burrows pooled). Abbreviations are used in Figs. 2 to 4

\begin{tabular}{|c|c|c|}
\hline Taxon & $\begin{array}{l}\text { Abbrevia- } \\
\text { tion }\end{array}$ & $\begin{array}{c}\text { Abundance } \\
(\%)\end{array}$ \\
\hline \multicolumn{3}{|l|}{ Gastropods } \\
\hline Fissurella crassa & FC & 42.0 \\
\hline F. $\operatorname{maxima} a^{a}$ & Fm & 2.1 \\
\hline F. costata & & 0.9 \\
\hline F. limbata & & 0.7 \\
\hline Collisella spp. & & 0.3 \\
\hline Scurria scurra & Ss & 0.9 \\
\hline S. parasitica & & 0.1 \\
\hline Prisogaster niger & $\operatorname{Pn}$ & 6.1 \\
\hline Tegula atra & $\mathrm{Ta}$ & 0.2 \\
\hline Diloma nigerrima & & 0.1 \\
\hline Littorina peruviana & & 0.3 \\
\hline Siphonaria lessoni & Sl & 0.2 \\
\hline Concholepas concholepas & $\mathrm{Cc}$ & 0.4 \\
\hline Trimusculus peruvianus & & $<0.1$ \\
\hline Bullimulus ${ }^{\mathrm{b}}$ & bu & 2.1 \\
\hline \multicolumn{3}{|l|}{ Chitons } \\
\hline Chiton granosus & & $<0.1$ \\
\hline Chiton spp. & Cs & 0.7 \\
\hline \multicolumn{3}{|l|}{ Bivalves } \\
\hline Perumytilus purpuratus & $\mathrm{Pp}$ & 8.3 \\
\hline Brachidontes granulata & & $<0.1$ \\
\hline Mesodesma donacium ${ }^{c}$ & & 0.7 \\
\hline Tagelus dombeii & & $<0.1$ \\
\hline \multicolumn{3}{|l|}{ Cirripedia } \\
\hline Austromegabalanus psittacus ${ }^{\mathrm{d}}$ & & 0.2 \\
\hline \multicolumn{3}{|l|}{ Decapods } \\
\hline Leptograpsus variegatus & Lv & 0.6 \\
\hline Acanthocyclus gayi & $\mathrm{Ag}$ & 6.3 \\
\hline A. hassleri & $\mathrm{Ah}$ & 2.9 \\
\hline Petrolisthes violaceus & $\mathrm{Pv}$ & 6.0 \\
\hline P. tuberculatus ${ }^{\alpha}$ & $\mathrm{Pt}$ & 2.1 \\
\hline P. granulosus & $\mathrm{Pg}$ & 0.6 \\
\hline P. laevigatus & & $<0.1$ \\
\hline Allopetrolisthes punctatus & Ap & 8.4 \\
\hline Pachycheles grossimanus ${ }^{\mathrm{d}}$ & Py & 0.4 \\
\hline Paraxanthus barbiger & $\mathrm{Pb}$ & 0.6 \\
\hline Homalaspis plana & $\mathrm{Hp}$ & 1.1 \\
\hline Taliepus dentatus & & 1.2 \\
\hline \multicolumn{3}{|l|}{ Asteroids } \\
\hline Heliaster helianthus & & 0.1 \\
\hline \multicolumn{3}{|l|}{ Echinoids } \\
\hline Loxechinus albus ${ }^{\mathrm{a}}$ & & $<0.1$ \\
\hline \multicolumn{3}{|l|}{ Fish } \\
\hline Aphos porosus & & 0.1 \\
\hline Sicyaces sanguineus & & 0.2 \\
\hline
\end{tabular}

of the littoral area of the marine preserve. Projected on the coastline, the transects of traps for $R$. norvegicus covered $176.6 \mathrm{~m}$, or $20.2 \%$ of the $874.3 \mathrm{~m}$ of coastline of the preserve (measured from aerial pictures as a smooth, not indented line at the high water level). The transects for A. olivaceus covered $154.0 \mathrm{~m}$, or $17.6 \%$ of the coastline inside the preserve. Although rats were present year-round in the marine preserve, their abundance $\left(N^{*}\right)$ fluctuated markedly during the year. Minimum abundance of about 6 individuals ( 4.4 ind. $\mathrm{ha}^{-1}$ ) was observed in winter (May through July) while maximum abundance of about 31 individuals (22.9 ind. $\mathrm{ha}^{-1}$ ) was observed in summer (January through March). The cricetid $A$. olivaceus exhibited a sudden increase in abundance between November and January, reaching maximum values of about 19 individuals (22.8 ind. ha $\left.{ }^{-1}\right)$. No individuals of this species were captured the rest of the year in the marine preserve. Mark-recapture trapping in Punta Salinas in August 1988 showed an estimated abundance $( \pm 95 \%$ $C I$ ) of $R$. norvegicus of $6.5 \pm 3.7$ individuals. The estimated abundance $( \pm 95 \% \mathrm{Cl}$ ) inside the marine preserve for the same month was $13 \pm 4.8$. In February 1989 no individuals were captured in Punta Salinas during 4 consecutive days and consequently trapping was suspended.

Comparison of the tracks left by the animals on smoked plates placed around the burrows with the laboratory track patterns showed that all burrows inside and outside the marine preserve were occupied only by Rattus norvegicus throughout the study. Indeed, $R$. norvegicus was the only species captured in the livetraps placed in the burrows toward the end of the study. Closer examination of the tracks suggested that each burrow was occupied by only 1 individual at the time, although not necessarily the same one throughout the study.

\section{Diet composition}

A total of 38 different prey items ( $N=997$ individuals) was found in burrows of Rattus norvegicus, including species obtained from the mid to the low intertidal zone (Table 2). Some of the prey species in the burrows are found almost exclusively amongst or inside holdfasts of the kelp Lessonia nigrescens in the very low intertidal zone (Cancino \& Santelices 1984). The remains also included 2 soft-bottom species of bivalves, a land snail (Table 2), and few carcasses of insects (not quantified). All the carapaces of the crab Petrolisthes violaceous and a few of other porcelanid species had a small cracked hole in the posterior end of the cephalothorax.

The keyhole limpet Fissurella crassa was the most 


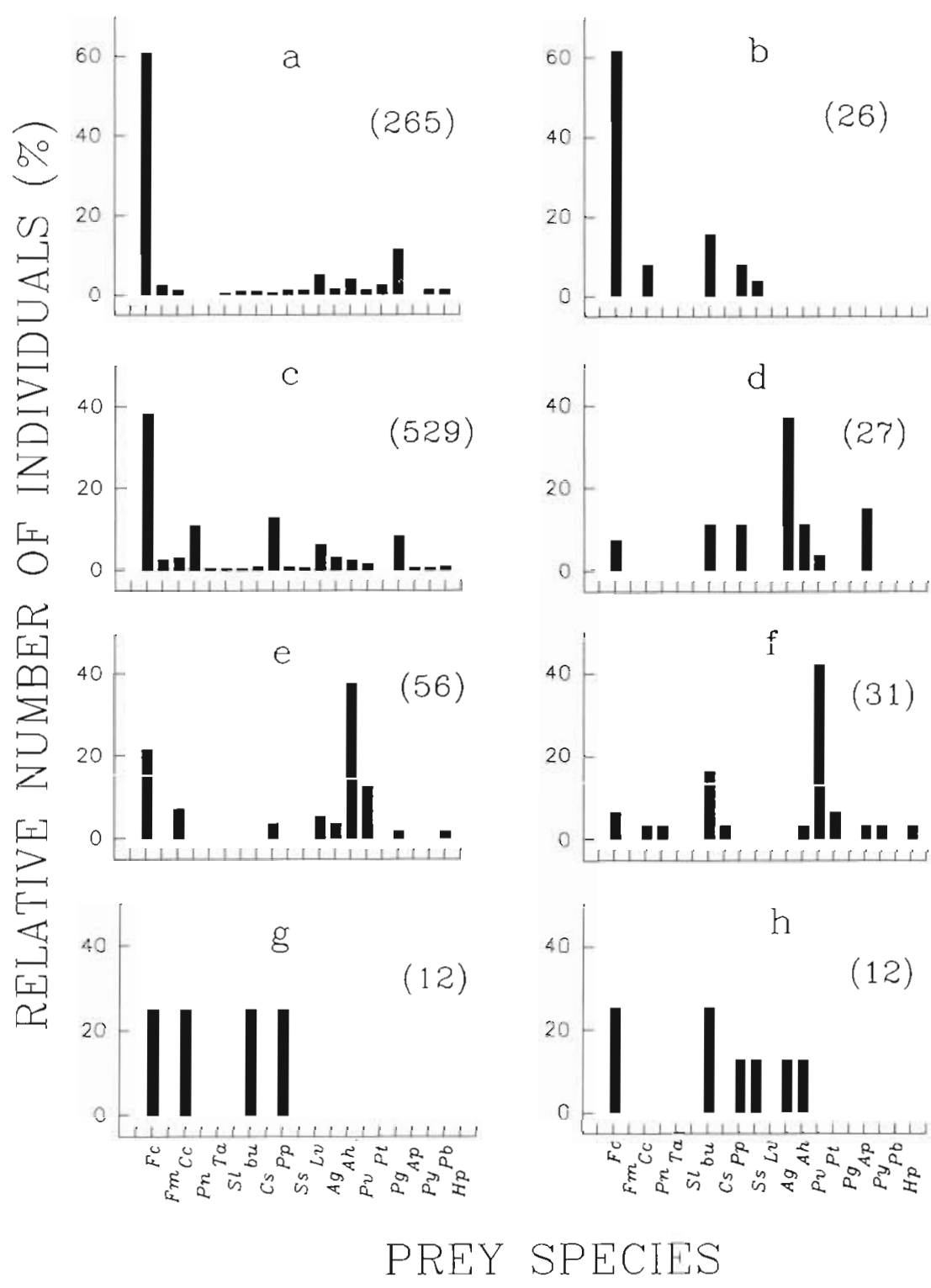

Fig. 2. Relative number of individuals ( $\%$ of total, months pooled) for the 20 most abundant prey species found in 8 burrows (a to h) of Rattus norvegicus inside the marine preserve of Las Cruces. Numbers in brackets are the total number of individuals per burrow. The abbreviations for species names are presented in Table 2 were observed. Some were dominated by keyhole limpets (Burrows a to $c_{1}$ Fig 2) and others by crabs (Burrows d to f, Fig. 2). Pooling all burrows together, keyhole limpets (all Fissurella species) and crabs (all decapod species) were the most abundant items throughout the year (Fig. 3). Mussels (P. purpuratus) were also found in the burrows throughout the year, reaching maximum relative abundance in May $(27.5 \%)$. Snails (all species) were absent from the burrows in April, June, and August, and were most abundant in March $(12.5 \%)$.

The relative abundance of prey items also varied greatly between the 2 burrows outside the marine preserve, although in both of them the 3 species of Fissurella were absent (Fig, 4). Results of Bray-Curtis and NMS ordination showed that when considering simultaneously all 36 prey species (2 species of fish were not considered in the analysis) the burrows outside the preserve do not differ from the ones inside the marine preserve (no segregation of Burrows 9 and 10 from the rest in Fig. 5).

In the laboratory, Norway rats ate the live keyhole limpets and crabs Petrolisthes violaceous they were of fered. Of the 8 carapaces of crabs preyed by rats, 6 had a small hole in the posterior, usually on the right side of the cephalothorax. The other 2 carapaces were completely crushed by the rats and only the claws and legs remained intact. Rats also ate the ham and part of the oats they were offered.

numerous prey species in the burrows inside the marine preserve, when considering all months together (Table 2, Fig 2). Other species of Fissurella, F. limbata and F. maxima, were also abundant. The crabs Allopetrolisthes punctatus, Acanthocyclus gayi, Petrolisthes violaceous, and Acanthocyclus hasssleri (in that order) were the second most numerous group of prey items, although they were not present in all burrows. The mytilid Perumytilus purpuratus and the muricid gastropod Concholepas concholepas were also numerous in some, but not all the burrows (Fig. 2). Differences among the composition of the burrows
Comparison between the sizes of keyhole limpets in the rat burrows and the relative abundance of those sizes in the field showed that rats feed on the smaller, relatively less abundant individuals of Fissurella crassa and F. Limbata (Fig. 6a, b). A similar pattern was observed for the muricid predatory snail Concholepas concholepas, in which the size mode captured by rats was clearly shifted toward small sizes, although some large snails were also eaten (Fig. 6c) The pattern for the small predatory crabs, Acanthocyclus gayi and A. hassleri, was different. These crabs attain a maximum size of about $30 \mathrm{~mm}$ in carapace width (CW; Navarrete 


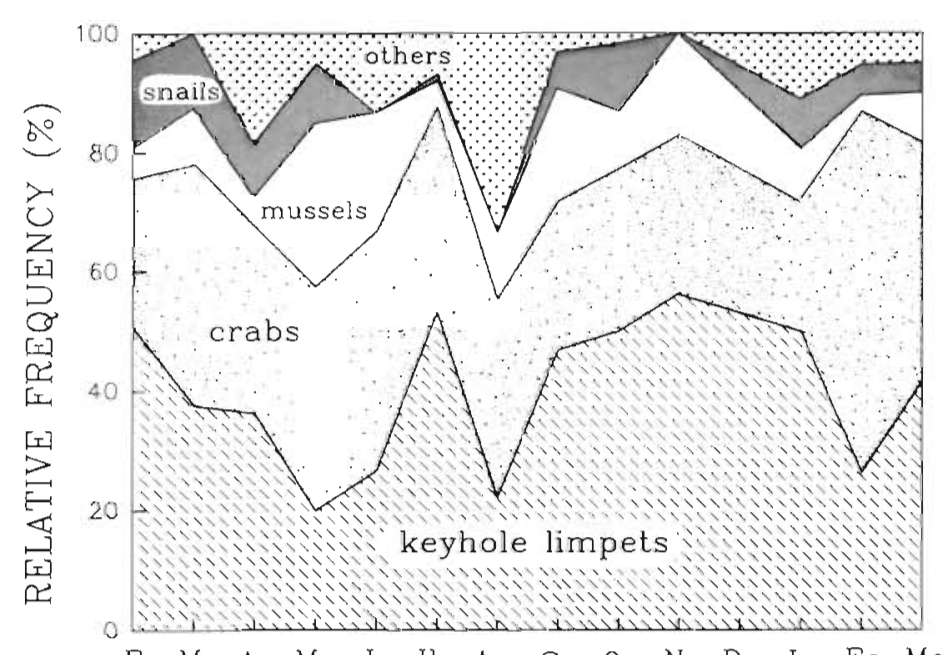

Fe Ma Ap My Ju Jl Au Se Oc No De Ja Fe Ma

\section{MONTH}

Fig. 3. Relative number of individuals of keyhole limpets (all Fissurella species pooled), crabs (all decapod species pooled), mussels (Perumytilus purpuratus), snails (herbivorous and carnivorous species pooled), and other prey found in burrows of Rattus norvegicus during the year. Prey from all burrows have been pooled

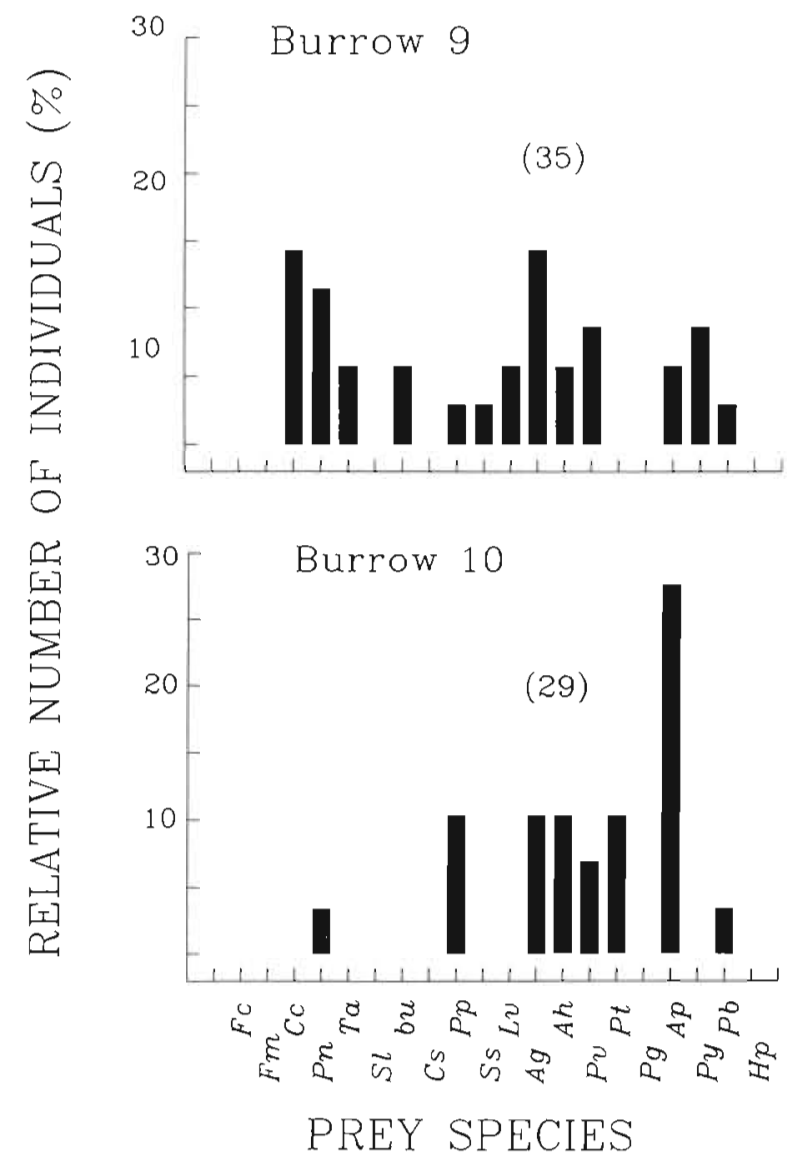

Fig. 4. Relative number of individuals ( $\%$ of total, months pooled) for the 20 most abundant prey items of Rattus norvegicus in 2 burrows outside the marine preserve in Las Cruces
\& Castilla 1990a). Rats captured individuals from the largest size classes found in the field (Fig. 7a, b). The mean size (carapace length \pm SE) of Allopetrolisthes punctatus captured by crabs (26.34 \pm 0.33 ) corrosponded to the largest size classes found in the holdfasts of Lessonia nigrescens (Cancino \& Santelices 1984, p. 29).

The total biomass of invertebrate species (fresh weight of all species and all burrows pooled together) found in rat burrows inside the marine preserve fluctuated greatly during the year (Fig. 8). No clear seasonal pattern was detected. However, a positive, although not significant relationship ( $p=0.065$, linear regression analysis) was observed between the biomass found in the burrows per month and the number of days of nocturnal low tides (tidal heights $\leq 0.30 \mathrm{~cm})$ predicted for that month was observed (Fig. 8)

Intertidal prey items were found with relatively high frequency in stomachs of Rattus norvegicus, including nereid polychaetes, the shrimp Alpheus sp., and red algae, that were not recorded in the burrows. Terrestrial prey items, mostly insects, plants, and seeds were also found in the stomachs (Table 3 ). Intertidal items made up $42.5 \%$ of all prey items found in the stomachs. Stomach contents of house mice Mus musculus con-

\section{BURROWS IN SPECIES SPACE}

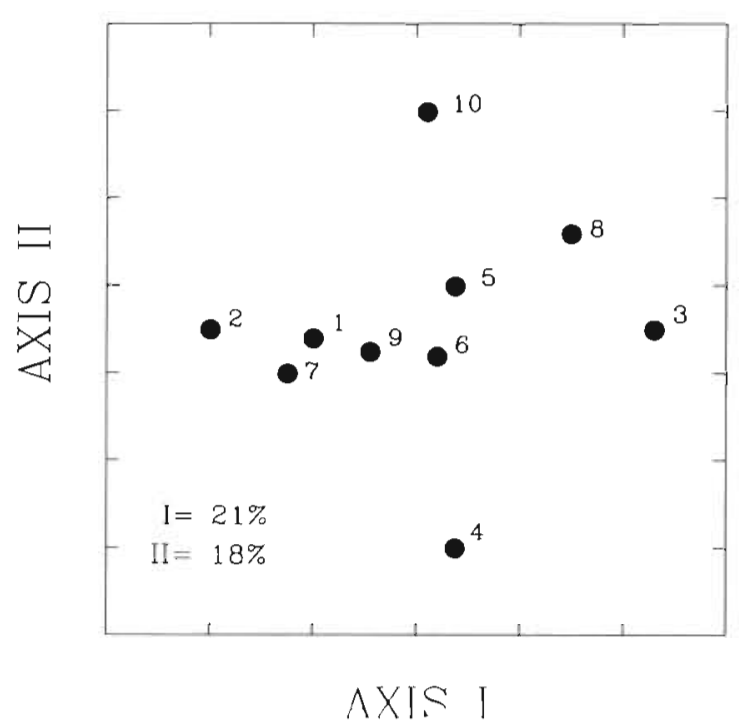

Fig. 5. Configuration of burrows of Rattus norvegicus (1 to 10) in species space, using Bray-Curtis and NMS ordinations on number of individuals of 36 prey species (see text). Burrows 1 to 8 are inside the marine preserve of Las Cruces, Burrows 9 and 10 outside. The percentage of the variance explained by the first 2 axes is indicated 


\section{Fissurella crassa}

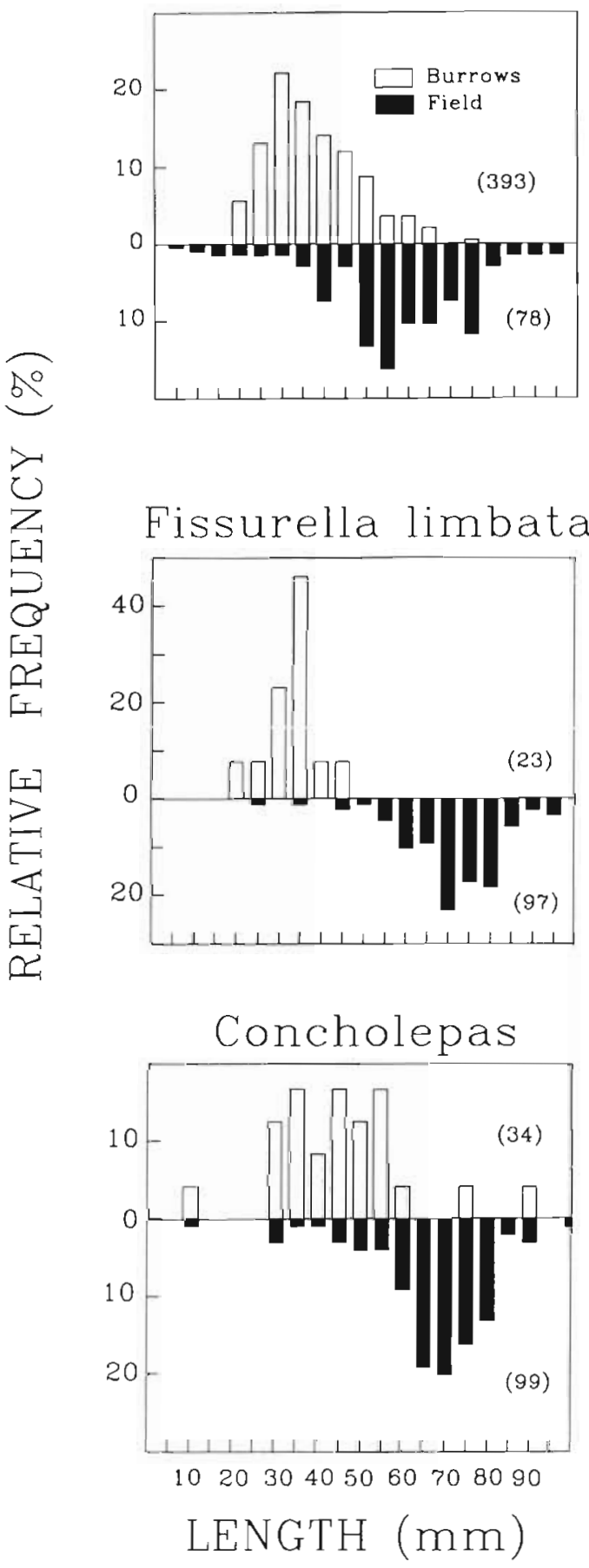

Fig. 6. Relative frequency of size classes of the keyhole limpets Fissurella crassa and F. limbata, and the muricid predatory gastropod Concholepas concholepas inside rat burrows and in the field. Sample sizes in parenthesis

tained remains of intertidal organisms (decapods, gastropods, and red algae), as well as plants and seeds. Intertidal items (pooled) made up to $46.7 \%$ of the stomachs of this species (Table 3 ).
Acanthocyclus gayi
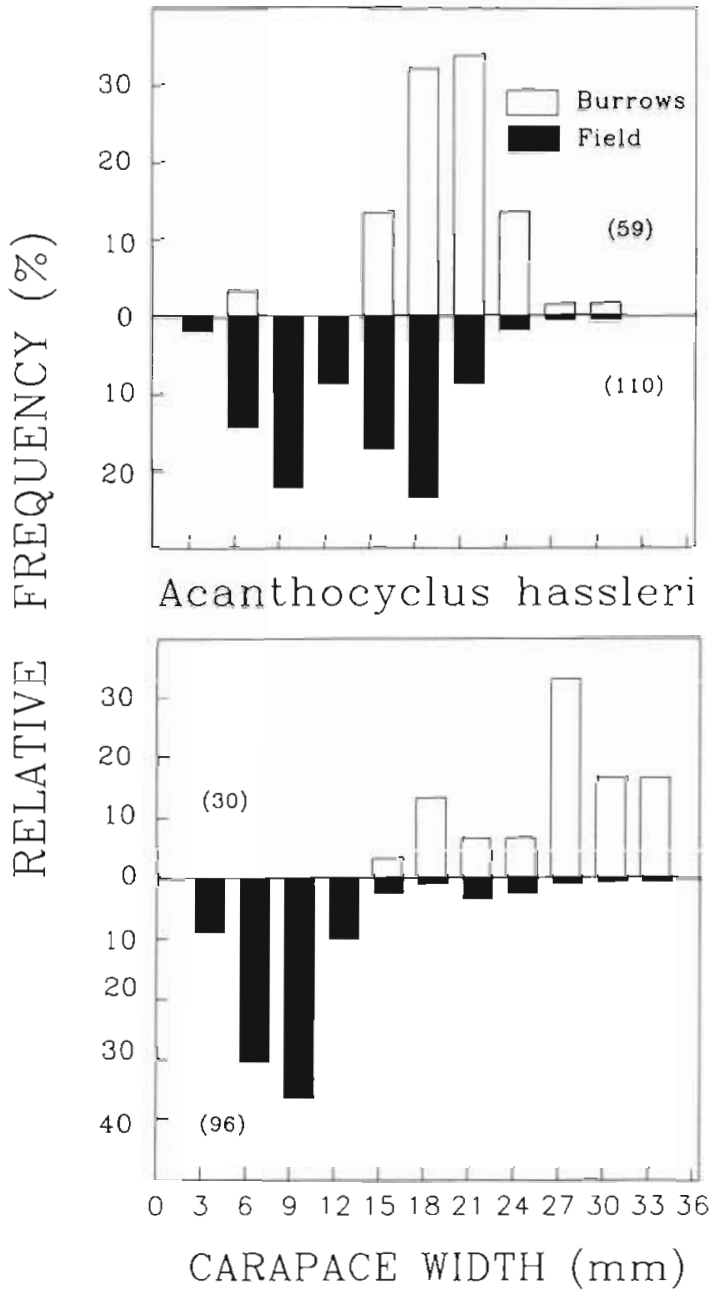

Fig. 7. Relative frequency of size classes of the predatory crabs Acanthocyclus gayi and A. hassleri inside rat burrows and in the field. Sample sizes in parenthesis

\section{DISCUSSION}

This study shows that Norway rats Rattus norvegicus are another, potentially important (see below) kind of intertidal predators. These rather unusual predators have not been previously reported to forage in the highly wave exposed intertidal zone of central Chile and only recently were they known to have such activities in the intertidal zone of southern Chile (Martinez et al. 1986, Zamorano 1986). The absence of systematic studies on predation by 'terrestrial' predators such as rats, mice, and racoons on intertidal communities might reflect the absence of these predators from other coasts around the world, or a bias of marine ecologists to disregard 'non-intertidal' predators. This study and previous reports by Martínez et al. (1986) and 


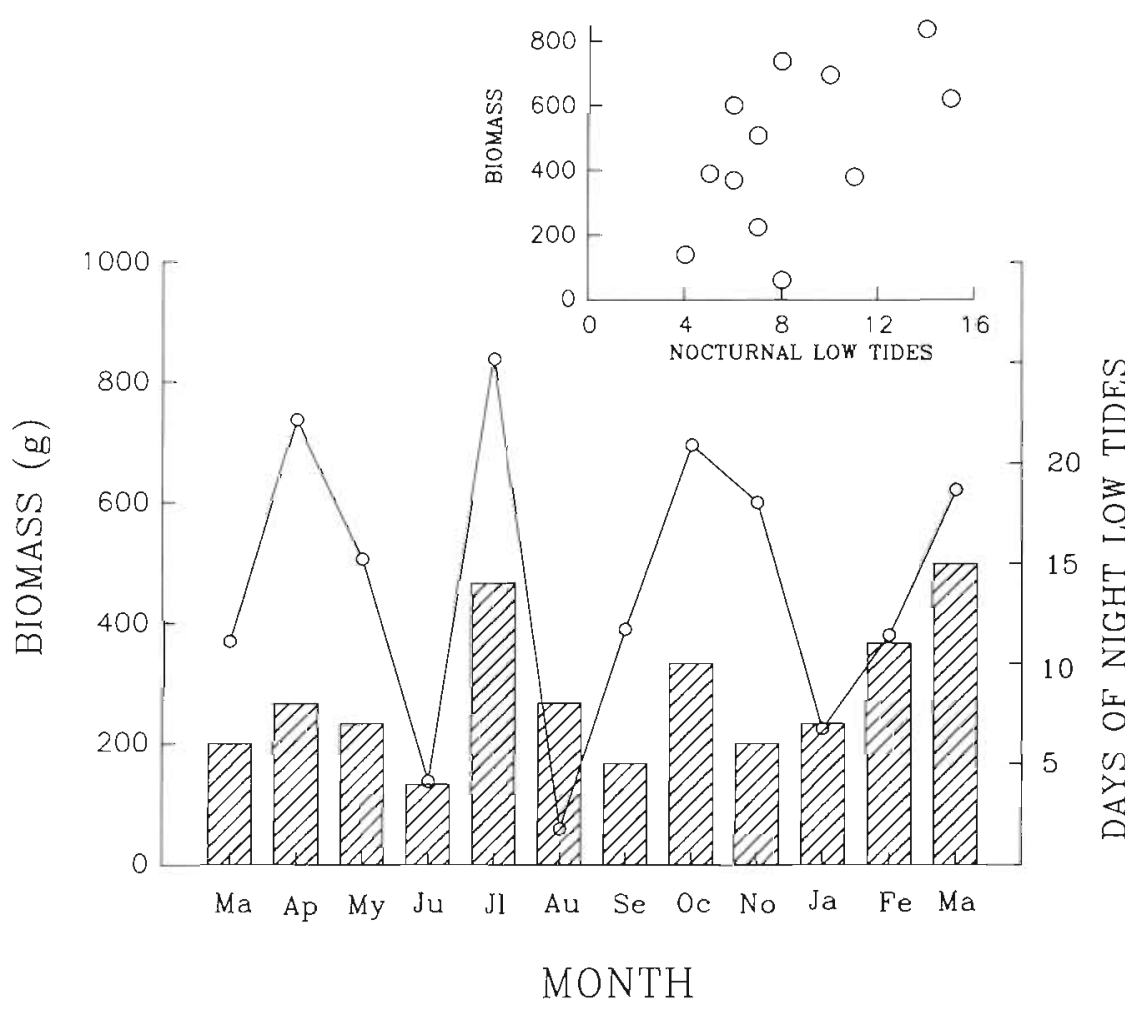

Fig. 8. Monthly total biomass (0; $\mathrm{g}$ fresh weight) of intertidal invertebrates found in 8 burrows of Rattus norvegicus inside the marine preserve of Las Cruces, central Chile. Bars: no. of days of nocturnal low tides per month. Inset: relationship between biomass ( $y$-axis) and no. of days of low tides $(x$-axis $)(p=0.065, r=0.55)$

Zamorano (1986) should stimulate marine ecologists to take a closer look at this kind of terrestrial influence on intertidal systems. A better understanding of the links between ecosystems (i.e. terrestrial and marine intertidal, intertidal and pelagic) is necessary to addressing urgent ecological problems, such as pollution, habitat destruction, rapid species extinctions, and global climate change (Odum 1992, Navarrete et al. in press). reported to prey in the intertidal zone of southern Chile by Martinez et al. (1986) and Zamorano (1986), but it was not present in our study in Las Cruces. On the other hand, Marmosa elegans and Mus musculus have not been recorded for southern Chile, but they were captured in Las Cruces using similar methodology (live and snap traps).

It is difficult to obtain reliable estimates of abun-

Table 3. Prey items found in stomachs of Rattus norvegicus $(n=29)$ and Mus musculus $(n=6)$ in Las Cruces, Chile. The frequency is the proportion of individuals in which a particular prey item was found. Relative percentage (\%) is the proportion of a prey item in the diet pooling all individuals together Empty stomachs were not considered. $\mathrm{N}=$ total number of prey items examined

\begin{tabular}{|c|c|c|c|c|}
\hline & \multicolumn{2}{|c|}{ Rattus norvegicus ( $\mathrm{N}=73)$} & \multicolumn{2}{|c|}{ Mus musculus $(\mathrm{N}=15)$} \\
\hline & Frequency & Relative \% & Frequency & Relative $\%$ \\
\hline Decapods & 0.45 & 17.8 & 0.50 & 20.0 \\
\hline Polychaetes & 0.14 & 5.5 & 0 & 0 \\
\hline Gastropods & 0.28 & 12.3 & 0.50 & 20.0 \\
\hline Littorina peruviana & 0.10 & 4.1 & 0 & 0 \\
\hline Alpheus sp. & 0.06 & 1.4 & 0 & 0 \\
\hline Red algae & 0.03 & 1.4 & 0.16 & 6.7 \\
\hline Insects & 0.48 & 19.2 & 0 & 0 \\
\hline Woody plants & 0.31 & 12.3 & 0.14 & 6.7 \\
\hline Green plants & 0.31 & 12.3 & 0.50 & 20.0 \\
\hline Seeds & 0.14 & 5.5 & 0.67 & 26.6 \\
\hline Spiders & 0.07 & 2.7 & 0 & 0 \\
\hline Rocks & 0.07 & 2.7 & 0 & 0 \\
\hline Other & 0.07 & 2.7 & 0 & 0 \\
\hline
\end{tabular}


dance of small mammals using mark-recapture methods when population sizes are small (Seber 1986, Menkens \& Anderson 1988). Under such circumstances and when there is no knowledge about the behavior of the species regarding the trapping study, the Lincoln-Peterson index $\left(N^{*}\right)$ used in this study gives the best estimates of population size (Menkens \& Anderson 1988). The transects for Rattus norvegicus and Akodon olivaceus sampled different effective areas due to differences in their home ranges (see above). Although there are some difficulties in applying the method of the home range proposed by Dice (1938) to estimate these effective areas (see Wilson \& Anderson 1985 and Seber 1986 for discussion), the densities of both $R$. norvegicus and $A$. olivaceus obtained for the preserve are well within the range of densities reported in the literature for other parts of the country (Redford \& Eisenberg 1992). Since the transects for $R$. norvegicus covered $15.2 \%$ of the area of littoral zone inside the marine preserve, a rough estimate of the total number of rats in the preserve can be obtained multiplying the values of $N^{*}$ in Fig. 1 by 6.6. A Inove conservative estimatc of only 5 times $N^{*}$ is obtained by using the projected proportion of the coastline covered by the transects $(20.2 \%)$.

Seasonal fluctuation in the abundance of $A$. olivaceus and $R$. norvegicus, with peaks in summer and lows in winter, have been also reported for the species in more terrestrial habitats (Muñoz-Pedreros et al. 1990, J. E. Jímenez pers. comm.).

\section{Behavior of Rattus norvegicus}

Digging and utilization of burrows by Rattus norvegicus is a well known behavior of both laboratory and wild strains of the species (Price 1977, Nieder et al. 1982). The burrows located in Las Cruces varied widely in size (ca 8 to $40 \mathrm{~cm}$ in diameter) and in the frequency of use by the animals (as revealed by the number of tracks left in smoked plates around the burrows and by the total number of prey found in them; Fig. 2). It seems that some of the burrows are used on a more or less permanent basis, while others are used only occasionally to eat prey captured in the intertidal zone. The presence of the owl Tyto alba (mostly a nocturnal predator; Jaksic et al. 1981) in the littoral zone of the marine preserve and the finding of remains of a small $R$. norvegicus in pellets of this predator (pers. obs.), suggests that rats may use burrows to seek refuge from predators while eating prey. Indeed, central place foraging behavior (a predator that returns to the same place after each foraging bout) has been observed in rats in the laboratory (Phelps \& Roberts 1989) and in the field (Parisi \& Gandolfi 1974, Nieder et al. 1982).
Nieder et al. (1982) observed rats under semi-natural conditions bringing most of the food (>90\%) they collected to burrows, but sometimes they ate the prey and leave the remains in sort of temporary refuges along pathways to the burrows. Some of the burrows with low numbers of intertidal prey found in Las Cruces might be this kind of refuge for the rats. In any case, since rats do not bring all the prey they capture to burrows, the total numbers of intertidal prey in the burrows of Las Cruces should be considered an underestimation of the total numbers captured by rats. Also, some items might be brought back to the burrows more than others, biasing their representation in the burrows.

\section{Diet composition}

Rattus norvegicus are generalized predators with an cxtremely broad diet encompassing in this case 41 different species of intertidal organisms. Despite this broad diet, however, variation in prey composition between burrows suggests that individuals tend to nrefer or be better at preying on either keyhole limpets or crabs, the numerically most important prey items in their diet. Analysis of stomach contents revealed the importance (relative abundance) of intertidal prey in the diet of the rats, as intertidal prey made more than $40 \%$ of the total food items. Similarly, analysis of stomach contents of the house mouse Mus musculus showed that intertidal prey can be an important part of the diet of this species as well. The presence of prey species from the very low intertidal zone inside the burrows suggest that rats forage close to the water and it is possible that they get in the water and perhaps dive to capture prey. Indeed, rats are known to be good swimmers and divers in rivers, where they capture snails and mussels (Parisi \& Gandolfi 1974, Nieder et al. 1977, 1982). Interestingly, during the course of the mark-recapture study, most of the animals released in the field after being marked ran down toward the ocean and a few swam across small tidepools to seek refuge in crevices, instead of running up toward the nearby vegetation.

The absence of most keyhole limpet species in the burrows outside the marine preserve suggests some degree of separation between individual rats preying inside and outside the preserve. However, when comparing the burrows in a multivariate setting using all prey species, no clear differences between inside and outside the preserve were found. Moreover, 2 species of soft-bottom bivalves that normally are not present inside the preserve (there are no sandy beaches inside the preserve) were found in the rat burrows inside the preserve. Although small sample sizes outside the preserve ( 2 burrows) difficult these comparisons, it seems 
likely that the fences of the preserve, designed to prevent trespassing of humans, do not stop the movement of rats through them.

\section{Potential effects on intertidal communities}

Rats prey on the mussel Perumytilus purpuratus, the competitive dominant for primary space (Paine et al. 1985). If this predation occurred frequently, they could have an impact on the entire community (e.g. Paine 1966). However, it seems unlikely that they have much effect on the mussel population because of the low number of individuals found in the burrows. Rats also prey on the keystone predator Concholepas concholepas (Castilla \& Durán 1985), but the numbers and frequency of capture of this species were also low. The potentially most important effects of rats in the marine preserve is on the keyhole limpet Fissurella crassa and F. limbata. Rats fed on the smaller and less abundant size classes of these species. This size-selective predation may reflect mechanical restrictions to dislodging larger individuals. Considering the number of keyhole limpets found in 8 rat burrows in a year (451), and an estimated population of rats of $31 \times 5(=155)$ individuals for the marine preserve (see above), rats can remove over 8738 small (20 to $55 \mathrm{~mm}$ long) keyhole limpets in a year. Considering an average density of small limpets of about $5.2 \pm 3.5$ ind. $\mathrm{m}^{-2}$ (Oliva \& Castilla 1986, S. Navarrete unpubl. data), a strip of intertidal about $5 \mathrm{~m}$ wide (tidal range is about $1.5 \mathrm{~m}$ ) in the low intertidal zone where the limpets are found, and $1780 \mathrm{~m}$ of coast (measured from aerial pictures as the rough line of coast at the high water level with all channels and major indentations but not considering rocky islets), the marine preserve contains a total of about 46200 small keyhole limpets. Thus, Norway rats could potentially remove ca $19 \%$ of the small limpets in the marine preserve in a year, which could have important effects on the population structure and abundance of these herbivorous species. In turn, keyhole limpets seem to be able to control the abundance of algae in the low intertidal zone when harvesting by humans is prevented (Oliva \& Castilla 1986). Outside the marine preserve, where populations of keyhole limpets are depleted by humans (Oliva \& Castilla 1986, Durán et al. 1987), the effects of rats could be swamped by human harvesting. When human harvesting is prevented (inside the preserve), rats could compensate for part of the effects of humans on keyhole limpet populations.

Rat abundance appeared higher in the marine preserve than in a human harvested locality, Punta Salinas, further from the village of Las Cruces and with a different littoral topography. Although replication of sites and long-term monitoring are necessary, these differences might suggest that rat abundance declines with distance from human populations, as shown in several other studies (Childs 1986, Brodie 1988, Glass et al. 1988, Redford \& Eisenberg 1992). If this is the case, the distance from sea-villages and cities may be an important factor in deciding locations of marine preserves.

Acknowledgements. We are grateful for the help of a number of enthusiastic young marine ecologists at ECIM who (courageously) opened stomachs, cut toes, smoked plates, and chewed oats for us. Of these, C. Espoz, J. Alvarado, W. Andrade and L. Weber were instrumental. For advice during this project and comments on earlier versions of the manuscripts we thank G. Allison, F. Jaksic and P. Marquet. Comments and suggestions by B. Menge, D. Steller, and 2 anonymous referees were most useful. This research was funded through FONDECYT, projects 88/0432 and 89/3503 to J.C.C. S.A.N acknowledges support from Beca de Instructor of the Departamento de Ecología (P.U.C.), Fulbright Fellowship, and Seaspace Scholarship.

\section{LITERATURE CITED}

Abrams, P. (1987). Indirect interaction between species that share a predator: varieties of indirect effects. In: Kerfoot, W. C., Sih, A. (eds.) Predation: direct and indirect impacts on aquatic communities. University Press of New England, Hanover, p. 38-54

Beals, E. W. (1984). Bray-Curtis ordination: an effective strategy for analysis of multivariate ecological data. Adv. ecol. Res. 14: 1-55

Brodie, J. (1988). Mammalian predation on Norway rats (Rattus norvegicus) living in a rural environment. J. Zool., Lond. 216: $582-583$

Bustamante, R., Castilla, J. C. (1990). Impact of human exploitation on populations of the intertidal southern bull-kelp Durvillea antarctica (Phaeophyta, Durvilleales) in central Chile. Biol. Conserv. 52: 205-220

Calhoun, J. B. (1962). The ecology and sociology of the Norway rat. U.S. Department of Health, Education, and Welfare Publ. 1008, Bethesda, MD

Cancino, J., Castilla, J. C. (1988), Emersion behaviour and foraging ecology of the common Chilean clingfish Sicyases sanguineus (Pisces: Gobiesocidae). J. nat. Hist. 22: $249-261$

Cancino, J., Santelices, B. (1984). Importancia ecológica de los discos adhesivos de Lessonia nigrescens Bory (Phaeophyta) en Chile central. Rev chil. Hist. nat. 57: 23-33

Castilla, J. C. (1981). Perspectivas de investigación en estructura y dinámica de comunidades intermareales rocosas de Chile Central. II. Depredadores de alto nivel trófico. Medio ambiente 5: 190-215

Castilla, J. C. (1988). Ecosistemas intermareales y submareales de fondos duros en el cono sur de Sudamérica: una oportunidad única para estudios regionales integrados. Inf. UNESCO Cienc. Mar 47: 115-123

Castilla, J. C., Durán, L. R. (1985). Human exclusion from the rocky intertidal zone of central Chile: the effects on Concholepas concholepas (Gastropoda). Oikos 45: $391-399$ 
Castilla, J. C., Paine, R. T (1987). Predation and community organization on Eastern pacific, temperate zone, rocky intertidal shores. Rev. chil. Hist. nat. 60: 131-151

Childs, J. E. (1986). Size-dependent predation on rats (Rattus norvegicus) by house cats (Felis catus) in an urban setting. J. Mammal. 67: 196-199

Connell, J. H. (1975). Some mechanisms producing structure in natural communities: a model and evidence from field experiments. In: Cody, M. L., Diamond, J. M. (eds.) Ecology and evolution of communities. Belknap-Harvard University Press, Cambridge, p. 460-490

Dice, L. R. (1938). Some census methods for mammals. J. Wildl. Mgmt 2: 119-130

Durán, L. R., Castilla, J. C. (1989). Variation and persistence of the middle rocky intertidal community of central Chile, with and without human harvesting. Mar. Biol. 103 $555-562$

Durán, L. R., Castilla, J. C., Oliva, D. O. (1987). Intensity of human predation on rocky shores at Las Cruces in central Chile. Environ. Conserv. 14: 143-149

Edwards, D. C., Conover, D. O., Sutter, F. III (1982). Mobile predators and the structure of marine intertidal communities. Ecology 63: 1175-1180

Feare, C. S., Summers, R. W. (1986). Birds as predators on rocky shores. In: Moore, P. G., Seed, R. (eds.) The ecology of rocky coasts. Columbia University Press, New York, p. $249-264$

Frank, H.W. (1965). The biodemography of an intertidal snail population. Ecology 46: 831-844

Gaines, S. D. (1983). Diverse consumer guilds in intertidal communities of Oregon and the Republic of Panama and their effects on prey assemblages. Ph.D. dissertation, Department of Zoology, Oregon State University, Corvallis

Gaines, S. D. (1985). Herbivory and between-habitat diversity: the differential effectiveness of defenses in a marine plant. Ecology 66: 473-485

Glass, G. E, Korch, G. W., Childs, J. E. (1988). Seasonal and habitat differences in growth rates of wild Rattus norvegicus. J. Mammal. 69: 587-592

Hanson, J. M., Mackay, W. C., Prepas, E. E. (1989). Effect of size-selective predation by muskrats (Ondatra zebithicus) on a population of unionid clams (Anodonta grandis simposiana). J. Anim. Ecol. 58: 15-28

Hughes, R. N. (1986). Rocky shore communities: catalysts to understand predation. In: Moore, P. G. Seed, R. (eds.) The ecology of rocky coasts. Columbia University Press, New York, p. 223-233

Kerfoot, W. C., Sih, A. (eds.) (1987). Predation: direct and indirect impacts on aquatic communities. University Press of New England, Hanover

Kruscal, J. B. (1964). Nonmetric multidimensional scaling: a numerical method. Psychometrika 29: 115-129

Jaksic, F. M., Greene, H. W., Yánez, J. L. (1981). The guild structure of a community of predatory vertebrates in central Chile. Oecologia 49: 21-28

Justice, K. E. (1961). A new method for measuring home ranges of small mammals. J. Mammal. 42: 462-470

Lewis, J. R. (1964). The ecology of rocky shores. English University Press, London

Marquet, P. A., Navarrete, S. A., Castilla, J. C. (1990). Scaling population density to body size in rocky intertidal communities. Science 250: 1125-1127

Marsh, C. P. (1986). Rocky intertidal community organization the impact of avian predators on mussel recruitment. Ecology 67: 771-786

Martínez, D. R., López, D. A., Del Villar, M. L., Figueroa, F R.
Gajardo, H. F. (1986). Depredación de organismos intermareales por roedores. Biota, Osorno (Chile) 2: 87-90

McCune, B. (1991). Multivariate analysis on the PC-Ord system. Department of General Science, Oregon State University, Corvallis

Menge, B. A. (1982). Reply to a comment by Edwards. Conover, and Sutter. Ecology 63: 1180-1184

Menge, B. A. (1983). Components of predation intensity in the low intertidal zone of the New England rocky intertidal region. Oecologia 58: 141-155

Menge, B. A., Farrell, T. M. (1989). Community structure and interaction webs in shallow marine hard-bottom communities: tests of an environmental stress model. Adv. ecol. Res. 19: 189-262

Menge, B. A., Lubchenco, J., Ashkenas, L. R. (1985). Diversity, heterogeneity and consumer pressure in a tropical rocky intertidal community. Oecologia 65: 394-405

Menge, B. A., Lubchenco, J., Gaines, S. D., Ashkenas, L. R. (1986). A test of the Menge-Sutherland model of community organization in a tropical rocky intertidal food web. Oecologia 71. 75-89

Menge, B. A., Sutherland, J. P. (1987). Community regulation: variation in disturbance, competition, and predation in relation to environmental stress and recruitment. Am. Nat. 130: 730-757

Menkens, G. E, Anderson, S. H. (1988). Estimation of smallmammal population size. Ecology 69: 1952-1959

Vieserve, P. L. (1981). Resource partitioning in a Chilean semiarid small mammal community. J. Anim. Ecol. 50: $745-757$

Moreno, C. A., Luneke, K. M., Lopez, M. I. (1985). The response of an intertidal Concholepas concholepas (Gastropoda) population to protection from man in southern Chile and the effects on benthic sessile assemblages. Oikos 46: 359-364

Moreno, C. A., Sutherland, J. P., Jara, H. F. (1984). Man as a predator in the intertidal zone of southern Chile. Oikos 42 : $155-160$

Muñoz-Pedreros, A., Murúa, R., González, L. (1990). Nicho ecológico de micromamíferos en un agroecosistema forestal de Chile central. Rev. chil. Hist. nat. 63: 267-277

Murúa, R., González, L. (1979). Distribución de roedores silvestres en relación al habitat. An. Mus. Hist. nat. (Valparaíso) 12: 69-75

Murúa, R., Meserve, P. L., González, L. A., Jofre, C. (1987). The small mammal community of a Chilean temperate rain forest: lack of evidence of competition between dominant species. J. Mammal. 68: 729-738

Navarrete, S. A., Castilla, J. C. (1988). Foraging activities of Chilean intertidal cabs Acanthocyclus gayi MilneEdwards et Lucas and A. hassleri Rathbun. J. exp. mar Biol. Ecol. 118: 115-136

Navarrete, S. A., Castilla, J. C. (1990a). Resource partitioning between intertidal predatory crabs: interference and refuge utilization. J. exp. mar. Biol. Ecol. 143: 101-129

Navarrete, S. A., Castilla, J. C. (1990b). Barnacle walls as mediators of intertidal mussel recruitment: effects of patch size on the utilization of space. Mar Ecol. Prog. Ser. 68: $113-119$

Navarrete, S. A., Lubchenco, J., Castilla, J. C. (in press). Pacific Ocean coastal ecosystems and global climate change. In: Mooney, H. A., Kronberg, B., Fuentes, E. R., Fuenzalida, H. (eds.) Contrasts in global change responses between North and South America. Academic Press, San Diego

Nieder, L., Cagnin, M., Parisi, V. (1982). Burrowing behaviour in the rat. Anim. Behav. 30: 837-844 
Nieder, L., Parisi, V., Tosi, L. (1977). Comportamento alimentare del ratto, Rattus norvegicus (Berk.), in ambienti salmastri dell'alto Adriatico. Ateneo Parmense, acta Nat. 13 $457-475$

Odum, E. P. (1992). Great ideas in ecology for the 1990s, a commentary. Bioscience (in press)

Oliva, D. O., Castilla, J. C. (1986). The effect of human exclusion on the population structure of key-hole limpets Fissurella crassa and F. limbata on the coast of central Chile. P.S.Z.N. I: Mar. Ecol. 7 201-217

Otis, D. L., Burnham, K. P., White, G. C., Anderson, D. R. (1978). Statistical inference from capture data on closed animal populations. Wildl. Monogr. 62: 1-135

Paine, R. T (1966). Food web complexity and species diversity. Am. Nat. 100:65-75

Paine, R. T (1980). Food webs: linkage, interaction strength and community infrastructure. J. Anim. Ecol 49: 667-685

Paine, R. T., Castilla, J C., Cancino, J. (1985). Perturbation and recovery patterns of starfish-dominated intertidal assemblages in Chile, New Zealand, and Washington State. Am. Nat. 125: 679-691

Paine, R. T., Palmer, R. (1978). Sicyases sanguineus: a unique trophic generalist from the Chilean intertidal zone. Copeia 1: $75-81$

Parisi, V., Gandolfi, G. (1974). Further aspects of the predation by rats on various molluscs species. Boll. Zool. 41: 87-106

Peterson, C. H. (1979). The importance of predation and competition in organizing the intertidal epifaunal communities of Barnegat Inlet, New Jersey. Oecologia 39: 1-24

Phelps, M. T., Roberts, T. A. (1989). Central place foraging by Rattus norvegicus on a radial maze. J. Comp. Psychol. 103: $326-338$

Price, E. O. (1977). Burrowing in wild and domestic Norway rats. J. Mammal. 58: 239-240

Redford, K. H., Eisenberg, J. F. (1992). Mammals of the neo-

This article was presented by C. H. Peterson, Morehead City, N. Carolina, USA tropics. The southern cone. Vol. 2. University of Chicago Press, Chicago

Robles, C. (1987). Predator foraging characteristics and prey community structure on a sheltered shore. Ecology 68 : $1502-1514$

Santelices, B. (1989). Algas marinas de Chile. Ediciones Universidad Católica de Chile, Santiago

Santelices, B. (1990). Patterns of organization of intertidal and shallow subtidal vegetation in wave exposed habitats of central Chile. Hydrobiologia 192: 35-57

Schoener, T W. (1989). Food webs from the small to the large. Ecology 70: 1559-1589

Seber, G. A. F. (1982). The estimation of animal abundance and related parameters. Griffen, London

Seber, G. A. F. (1986). A review of estimating animal abundance. Biometrics 42: 455-462

Sih, A., Crowley, P., McPeek, M., Petranka, J., Strohmeier, K. (1985). Predation, competition, and prey communities: a review of field experiments. A. Rev. Ecol. Syst. 16: 269-311

Stewart, D. T., Herman, T. B., Teferi, T. (1989). Littoral feeding in a high-density insular population of Sorex cinereus. Can. J. Zool. 67: 2074-2077

Tanaka, R. (1980). Controversial problems in advanced research on estimating population density of small rodents. Res. Population Ecol. Suppl. 2: 1-66

Van Cleave, H. (1940). Ten years of observation on a freshwater mussel population. Ecology 21: 363-370

Wilson, K. R., Anderson, D. R. (1985). Evaluation of a density estimator based on a trapping web and distance sampling theory. Ecology 66: 1185-1194

Zamorano, J. H. (1986). Rattus rattus (Rodentia, Muridae) un depredador intermareal poco conocido. Medio ambiente 8: $58-62$

Manuscript first received: September 3, 1992

Revised version accepted: November 23, 1992 